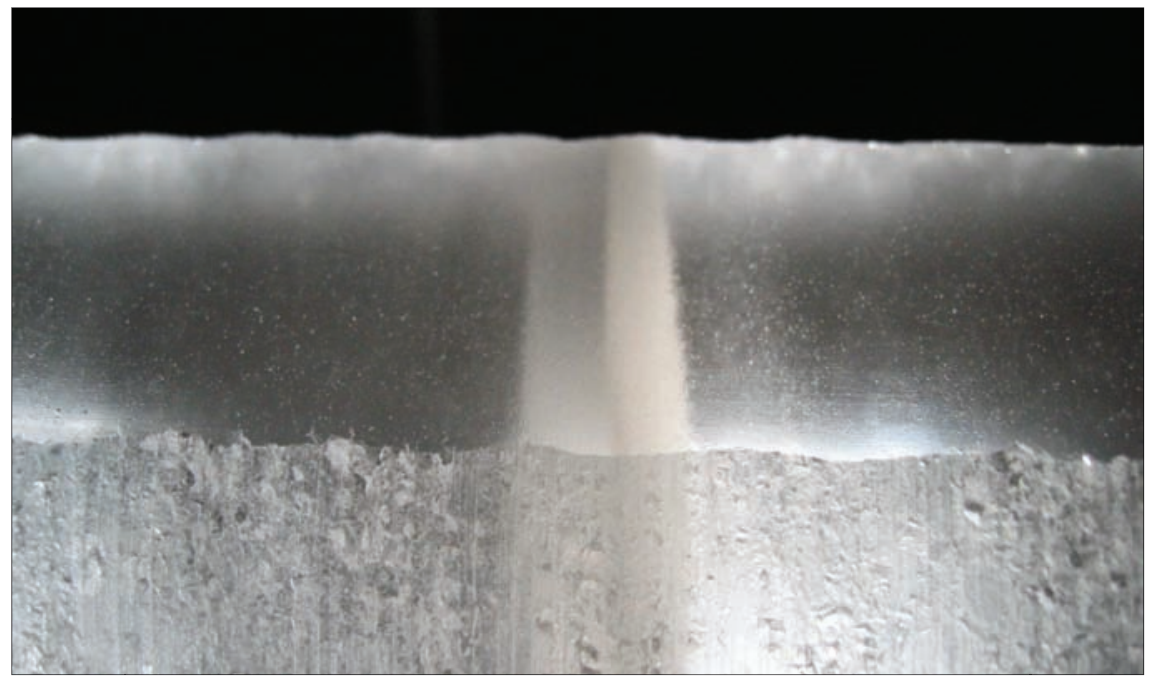

Fig. 2: A tephra layer in a half-cut ice core sample. There are a few tephra layers that were not found in the previous $2503 \mathrm{~m}$ deep ice core from Dome Fuji.

\section{Properties of the ice core}

In situ ECM (Electric Conductivity Measurement) and optical stratigraphic observations will be performed at Dome Fuji. The detailed analysis will be conducted in Japan, and we expect to determine the approximate age of the core by detecting glacial cycles and signals of the Brunhes-Matuyama magnetic reversal at around 780 $k a$, and by using a glaciological flow-model. It is difficult to say at present but we expect that the core may be $800 \mathrm{ka}$ old, as is the case for the Dome $\mathrm{C}$ deep ice core, or even older. This expected age is suggested from the fact that the geothermal heat flux in Dronning Maud Land where Dome Fuji is located is probably smaller than that of the eastern part of East Antarctica where Vostok and Dome C are located. We discovered new tephra layers (Fig. 3) that were not observed in the first $2503 \mathrm{~m}$ deep ice core.

\section{Outlook}

One half of the ice core will be kept in a storage trench at Dome Fuji and the other half will be brought back to Japan by our Antarctic research vessel in April. These ice cores will be used for various

\section{Project facts}

Project: Dome Fuji Ice Core

Contact: Yoshiyuki Fujii, fujii@nipr.ac.jp

Participants: Numerous scientists from the National Polar Institute, Tokyo, and several Japanese Universities.

Funding: Japanese National Funding

Where: Eastern Dronning Maud Land,

East Antarctica

When: 2004 ongoing

What: Deep ice cores to bedrock; Multiparameter analysis analyses at the National Institute of Polar Research, Hokkaido University, and other institutions in Japan. Our main research objectives are

1) To reconstruct the global climate and environmental changes that occurred during the past 800 ka to 1 million years.

2) To determine the impacts of the geomagnetic field reversal on the global climate and the environment around $780 \mathrm{ka}$ BP.

3) To clarify the relationship between the paleo-solar activity and the global climate.

4) To clarify the relationship between biological evolution of the ice core microbes and environmental changes.

Furthermore, if we can obtain samples of the bedrock, it may be possible to get information on the formative period of the Antarctic ice sheet in the Tertiary.

\section{REFERENCES}

Watanabe, 0., Jouzel, J., Johnsen, S., Parrenin, F., Shoji, H., and Yoshida, N., 2003: Homogeneous climate variability across East Antarctica over the past three glacial cycles, Nature, 422: 509-512.

Petit, J. R., Jouzel, J., Raynaud, D., Barkov, N.I., Barnola, J.-M., Basile, I., Bender, M., Chappellaz, J., Davis, M., Delaygue, G., Masson-Delmotte, V., Kotlyakov, V.M., Legrand, M., Lipenkov, V.Y., Lorius, C., Pepin, L., Ritz, C., Saltzman, E., and Stievenard M., 1999: Climate and atmospheric history of the past 420,000 years from the Vostok ice core, Antarctica, Nature, 399: 429-436.

\title{
Vostok Ice Core project
}

Vladimir Lipenkov ${ }^{1}$ on behalf of the Vostok Project Members

${ }^{1}$ Arctic and Antarctic Research Institute (AARI), St. Petersburg, Russia; lipenkov@aari.nw.ru

\section{Introduction}

Over the last 25 years, the three deep ice cores 3G, 4G and 5G, drilled at the Russian Vostok Station (Fig.1), have provided a wealth of information about past climate and environmental changes. At this site in East Antarctica, the ice thickness is $3750 \mathrm{~m}$ and the snow accumulation rate is only $2.1 \mathrm{~cm}$ of water equivalent per year. This provides the unique opportunity to obtain a long climatic record with relatively high time-resolution. In January 1998, the collaborative project between Russia, France and the United States to drill the $5 \mathrm{G}$ hole at Vostok yielded the Iongest ice core ever recovered, reaching a depth of $3623 \mathrm{~m}$. The drilling stopped $130 \mathrm{~m}$ above Lake Vostok, a deep subglacial water body that extends over a large area below the ice sheet. The $5 \mathrm{G}$ ice core can be separated into three distinct sections. The upper $3310 \mathrm{~m}$ of the core are characterized by an undisturbed sequence of ice layers. The analysis of this section of the core resulted in the first record of Antarctic ice extending through four climate cycles back to $420 \mathrm{kyr}$ BP (Petit et al., 1999). Between 3310 and $3539 \mathrm{~m}$, there are indications of ice-flow anomalies that could have altered the original stratig- 


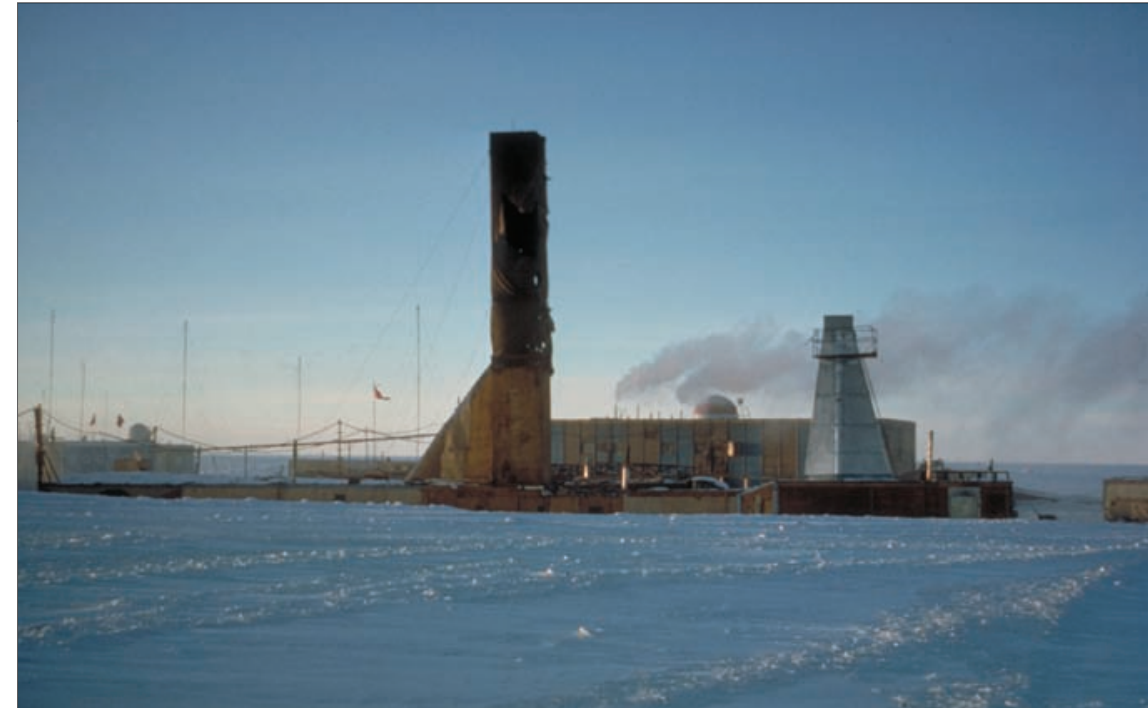

Fig. 1: Drill units at the Russian Vostok Station in East Antarctica.

raphy of glacial ice. Finally, below $3539 \mathrm{~m}$, the core consists of ice refrozen from lake water. Using an appropriate correction of the ice stratigraphy for flow disturbance in the 3320-3345 m interval, it has recently been possible to extend the Vostok ice record farther back to $440 \mathrm{kyr} B \mathrm{P}$, which implies full coverage of marine isotope stage (MIS) 11 (Raynaud et al., 2005).

\section{The 440 kyr climatic record from the Vostok ice core}

Figure 2 shows a series of selected Vostok records covering the last 440 kyr (adopted from Petit et al., 1999; Delmotte et al., 2004 and Raynaud et al., 2005). The records indicate that the climate on our planet during this time has always been in a state of change but with atmospheric and climate properties oscillating between stable bounds. Most of the climate variability during glacialinterglacial changes occurs with periodicities corresponding to that of the precession, obliquity and eccentricity of the Earth's orbit, with a larger concentration of variance in the 100-kyr band. The overall amplitude of the glacial-interglacial temperature change is $12^{\circ} \mathrm{C}$ at the ice-sheet surface, as judged from the Vostok isotope record.

The "sawtooth" pattern of the Vostok isotopic temperature record roughly mimics the sea level (reversed global ice volume) changes deduced from marine sediment studies. The much higher dust concentration during full glacial periods than during interglacials is interpreted as indicating more extensive deserts and continental areas (low sea

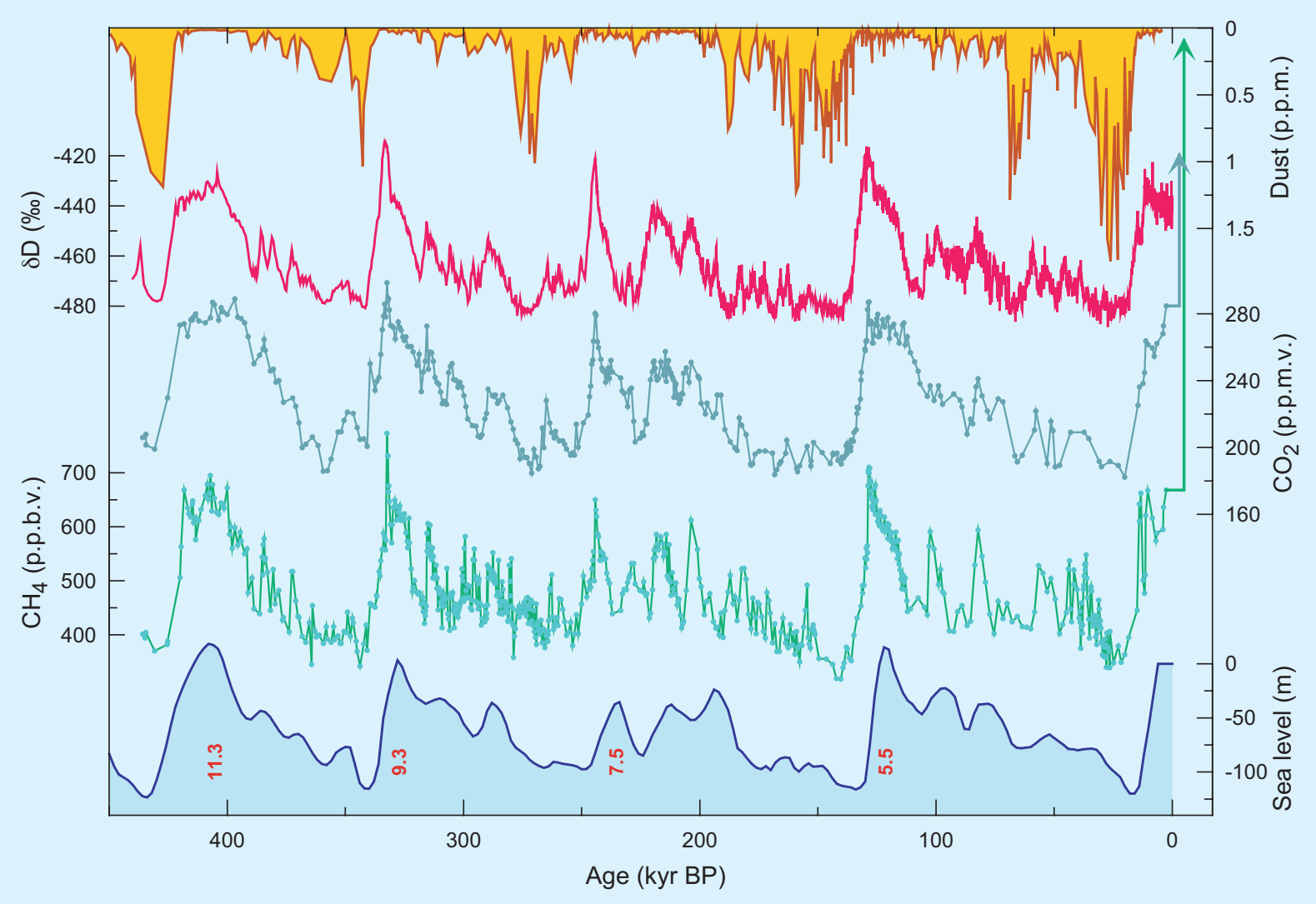

Fig. 2: Vostok time series and sea level derived by calibrating the marine $\delta^{18} \mathrm{O}$ record (Bassinot et al., 1994). The dust record provides information on aerosols of continental origin. The deuterium content of the ice $\delta D$ is taken as a proxy for Antarctic temperature; the warmest periods of the past correspond to MIS 5.5, 7.5, 9.3 and 11.3. The atmospheric concentrations of the two greenhouse gases $\left(\mathrm{CO}_{2}\right.$ and $\left.\mathrm{CH}_{4}\right)$ are measured on the air enclosed in the ice. The rapid anthropogenic rise in concentrations of $\mathrm{CO}_{2}$ and $\mathrm{CH}_{4}$ since the 1850's, up to present-day levels of 360 ppmv and 1750 ppbv, respectively, are indicated by arrows. The Vostok data (Petit et al., 1999; Delmotte et al., 2004; Raynaud et al., 2005) are plotted on the EDC2 timescale after Raynaud et al., 2005. 
level), more intense surface winds in the source regions, and/or more efficient meridional transport at the times of glacial maxima (Petit et al., 1999). The close linkage between climate and $\mathrm{CO}_{2}$ and $\mathrm{CH}_{4}$ concentrations documented in the Vostok core throughout the four climatic cycles supports the role of the greenhouse gases as amplifiers of initial orbital forcing.

The sequence of events during glacial terminations suggests that increases in Antarctic air temperature and atmospheric greenhouse gas concentrations lead sea level rise (Northern Hemisphere deglaciation) by a few thousands of years (Petit, et al., 1999, Sowers et al., 1991, Shackleton, 2000). It has also been shown that $\mathrm{CH}_{4}$ (Delmotte et al., 2004) and $\mathrm{CO}_{2}$ (Caillon et al., 2003; Fischer et al., 1999; Petit, et al., 1999; Pépin, et al., 2001) concentration increases lagged Antarctic warming by several hundreds of years. This natural scenario is, however, different from the present situation, where rise of greenhouse gases, as a result of anthropogenic activities, has been imposed first. The reconstructed record for MIS 11 indicates that concentrations of $\mathrm{CO}_{2}$ and $\mathrm{CH}_{4}$ throughout this 30-kyrlong interglacial period, which is considered an "orbital" analog for the Holocene, were close to the preindustrial levels and lower than during MIS 9.3 (Raynaud et al., 2005). Thus, the present-day increase in concentration of these greenhouse gases in the Earth's atmosphere seems to have been unprecedented during the past $440 \mathrm{kyr}$.

\section{Project facts}

Project: Vostok ice core project Contact: Vladimir Lipenkov, lipenkov@aari.nw.ru

Participants: Institutes and laboratories in Russia (AARI of Roshydromet; St. Petersburg Mining Institute; Institute of Microbiology, RAS; Kazan State University; Institute of Geography, RAS), in France (LGGE, CNRS, Université Joseph Fourier, Grenoble; Laboratoire des Sciences du Climat et de I'Environnement, CNRS-CEA, Saclay) and in the United States (laboratories funded by NSF).

Funding: The Vostok venture was made possible by the logistical support of Russian Antarctic Expedition (RAE), Institute Francais pour la Recherche et la Technologie Polaires (IFRTP) and the Office of Polar Programs (NSF). The development of drilling technology and the ice-core studies were funded by national contributions from Russia, France and the United States.

Where: East Antarctica $\left(78^{\circ} 28^{\prime} \mathrm{S}, 106^{\circ} 48^{\prime} \mathrm{E}\right.$, altitude $3488 \mathrm{~m}$ asl, ice thickness $3750 \mathrm{~m}$ )

When: 3 main deep holes (3G, 4G, 5G) were drilled from 1980 to 1998 . The ice core analyses are in progress.

What: 3 ice cores reaching depths of 2202 $m, 2546 \mathrm{~m}$ and $3623 \mathrm{~m}$. High-resolution records of atmospheric composition and climate covering the last $440 \mathrm{kyr}$.

Database: www.ncdc.noaa.gov/paleo/ icecore/antarctica/vostok/vostok.html

\section{Ongoing ice core studies}

Studies of the Vostok ice are now focused on the deepest section of the core, below $3310 \mathrm{~m}$. The extrapolation of the Vostok timescale to greater depths, made with the aid of an ice-sheet flow model, shows that the age of glacial ice just above its contact with accretion lake ice (at a depth of $3530 \mathrm{~m}$ ) may reach $\sim 2000$ kyr (Salamatin et al., 2004). We hope that the joint effort of scientists working in the fields of paleoclimate records and physical properties of ice will allow us to decipher information on some of the earlier climatic cycles archived in this section of the Vostok core. Meanwhile, comprehensive analysis of the now available accretion ice from depths below $3539 \mathrm{~m}$ is expected to provide a clue to understanding the extraordinary environment of subglacial Lake Vostok.

\section{References}

Caillon, N., Severinghaus, J., Jouzel, J., Barnola J.M., Kang, J. and Lipenkov, V.Ya., 2003: Timing of Atmospheric $\mathrm{CO}_{2}$ and Antarctic temperature changes across Termination III. Science, $\mathbf{2 9 9}$ 1728-1731

Masson-Delmotte, V., Chappellaz, J., Brook, E. Yiou, P., Barnola, J.M., Goujon, C., Raynaud, D. and Lipenkov, V.Ya., 2004: Atmospheric methane during the last four glacial-interglacial cycles:

Rapid changes and their link with Antarctic temperature. J. Geophys. Res., 109: D12104, doi: 10.1029/2003JD004417.

Fischer, H., Wahlen, M., Smith, J., Mastroianni, D. and Deck, B., 1999: Ice core records of atmospheric $\mathrm{CO}_{2}$ around the last three glacial terminations, Science, 283: 1712-1714.

Petit, J. R., Jouzel, J., Raynaud, D., Barkov, N.I., Barnola, J.-M., Basile, I., Bender, M., Chappellaz, J., Davis, M., Delaygue, G., Masson-Delmotte, V., Kotlyakov, V.M., Legrand, M., Lipenkov, V.Y., Lorius, C., Pepin, L., Ritz, C., Saltzman, E., and Stievenard M., 1999: Climate and atmospheric history of the past 420,000 years from the Vostok ice core, Antarctica, Nature, 399: 429-436.

Raynaud, D., Barnola, J.M., Souchez, R., Lorrain, R., Petit, J.R., Duval, P. and Lipenkov, V.Ya., 2005: The record for marine isotopic stage 11. Nature, $\mathbf{4 3 6}$ : 39-40.

Salamatin, A.N., Tsyganova, E.A., Lipenkov, V.Ya. and Petit, J.R., 2004: Vostok (Antarctica) ice-core time-scale from datings of different origins. Ann. Glaciol., 39: 283-292.

For full references please consult:

www.pages-igbp.org/products/newsletters/ref2006_1.html

\section{European Project for Ice Coring in Antarctica (EPICA)}

ERIC WolfF ${ }^{1}$ on behalf OF the EPICA COMMUNITY

'British Antarctic Survey, Cambridge, UK; ewwo@bas.ac.uk

\section{Introduction}

The last few hundred thousand years form the context in which we can learn how the Earth System (including its climate) works. Although the geological setting of the Earth was similar to today, very significant changes occurred in the climate, the circulation of the ocean, and the composition of the atmosphere. By learning about these changes, we can understand the processes that can occur, and that should be represented by models - the same models that will be used to predict future conditions.

Ice cores are particularly powerful because numerous climate responses and forcings (including greenhouse gas concentrations) are recorded in the same core. In early Antarctic cores covering complete glacial-interglacial cycles (notably Vostok and Dome Fuji), we were able to see the close connection between climate and greenhouse gas concentrations that prevailed through four glacial-interglacial cycles over the last $400 \mathrm{kyr}$ (Petit et al., 1999, Watanabe et al., 2003). 